\title{
Timbuctoo and the First Emancipation of the Early-Nineteenth Century By Guy Weston
}

\section{DOI: $\underline{\text { https://doi.org/10.14713/njs.v8i1.268 }}$}

Timbuctoo is an unincorporated community in Westampton Township, Burlington County, New Jersey. It was settled by formerly enslaved and free Black people beginning in 1826, reaching approximately 125 residents by 1860. The community also included at least two churches, two schools, and a benevolent association that helped people in the community in need. A vast collection of documentation of Timbuctoo's founding and early development is available for research, including more than 100 years of deed and legal documents in a single PDF file; deeds and certificates of incorporation for churches, schools, and the benevolent association; newspapers that include death notices and feature articles as early as 1851; as well as vital records. The vital records are found in the New Jersey Births and Christenings Index and the New Jersey Deaths and Burials Index, with Timbuctoo resident listings as early as the 1850s. Prompted by recent emphasis on celebrating the end of slavery with the establishment of Juneteenth as a national holiday, this article explores what emancipation meant for an antebellum free Black community in southern New Jersey, drawing substantially from the primary sources above to provide a unique contemporaneous perspective. Questions for future research are mentioned throughout the narrative to illuminate compelling potential research projects.

Legislation to make Juneteenth a national holiday calls attention to the end of racialized slavery in the United States and the history of emancipation efforts of the 1860s, namely, the Emancipation Proclamation, the end of the Civil War, and the ratification of the Thirteenth Amendment. Frequently missing from this discussion are what Arthur Zilversmit called "the First 
Emancipation," when northern states began passing legislation to end slavery, beginning in the late 1700s. With the exception of Vermont in 1777 and Massachusetts in 1783, where slavery was illegal immediately, these acts were gradual manumission laws. Gradual manumission phased out slavery over a period of decades. New Jersey was the last state to pass such legislation, in 1804. How should the end of slavery in New Jersey be commemorated? A review of New Jersey's complex history with slavery helps to address that question.

"An Act for the Gradual Abolition of Slavery"2 required the registration of births of the children of enslaved people born beginning on July 4, 1804, and declared such children to be "free," but bound as servants to the owners of their mothers for a period of twenty-five years for males and twenty-one years for females. Thus, those born on July 4, 1804, would complete their indentures in the 1820s. The New Jersey legislature did not address people who were born before July 4, 1804, until April 18, 1846, when "An Act to Abolish Slavery"3 was enacted, indicating that "every person who is now holden in slavery by the laws thereof is made free, subject, however, to the restrictions herein after mentioned and imposed." What were these restrictions? In brief, any remaining enslaved people were considered "apprenticed for life," and would need to buy out their indentures, or hope that their enslavers had a long-awaited awakening about the evils of "owning" people. Clearly, this new law provided for the continuation of slavery under a different label. However, the impact of the 1846 law is also questionable, since people born immediately before

\footnotetext{
${ }^{1}$ Arthur Zilversmit, The First Emancipation: The Abolition of Slaves in the North (Chicago: University of Chicago Press, 1967).

${ }^{2}$ Giles R. Wright, Afro-Americans in New Jersey: A Short History (Trenton, New Jersey Historical Commission, 1989), 25-26.

${ }^{3}$ Wright, Afro-Americans in New Jersey, 26.
} 
1804 would have been in their mid-forties. Those born earlier were even older. Mid-forties was the approximate average life expectancy in that era. ${ }^{4}$

New Jersey's characterization as resistant to emancipation is well documented: Giles Wright ${ }^{5}$ notes that New Jersey was the only northern state that failed to ratify the Thirteenth, Fourteenth, and Fifteenth Amendments, and was the only northern state that Lincoln did not carry in the 1860 election. In addition, he points out that 18 slaves were enumerated in the state in 1860 , noting that slavery was not abolished completely in New Jersey until the passage of the Thirteenth Amendment. Richard Marrin reminds us that by 1830, fully one-third of the 3,568 northern Black people still enslaved lived in New Jersey. ${ }^{6}$ As we discuss below, this statistic is misleading in the sense that the vast majority of people counted as enslaved were located in New Jersey's northern counties. Specifically, there were 2,221 enslaved persons enumerated in the northern counties of New Jersey and 33 enslaved persons in the southern counties in the 1830 census. $^{7}$

Figure $1^{8}$ shows New Jersey's population by race, specifying the number of enslaved and free people in the Black population. The majority of New Jersey's population is located in the northern "half" of the state, where $71 \%$ of the population lives. Therefore, any population characteristic that is dominant in the northern, more densely populated counties obscures trends in the southern counties.

\footnotetext{
${ }^{4}$ Clane L. Pope, “Adult Mortality in America before 1900: A View from Family Histories” in Strategic Factors in Nineteenth Century Economic History: A Volume to Honor Robert W. Fogel, Eds. Claudia Goldin and Hugh Rockoff (Chicago: University of Chicago Press, 1992), 267-296.

${ }^{5}$ Wright, Afro-Americans in New Jersey, 28-29.

${ }^{6}$ Richard B Marrin, Runaways of Colonial New Jersey: Indentured Servants, Slaves, Deserters, and Prisoners, 1720-1781 (Westminster, Heritage Books, 2007), 328.

${ }^{7}$ U.S. Census Bureau, Historical Statistics of the United States: Colonial Times to 1970. https://www.census.gov/history/www/through_the decades/overview/. Accessed on May 20, 2021.

${ }^{8}$ U.S. Census Bureau, Historical Statistics of the United States.
} 
Figure 1. New Jersey Population by County in 1830

\begin{tabular}{|c|c|c|c|c|c|c|c|}
\hline & \multirow{3}{*}{1830} & \multicolumn{2}{|c|}{ TOTAL POPULATION } & \multicolumn{4}{|c|}{ TOTAL BLACK POPULATION } \\
\hline & & & & Total & Slave & Free & Free \\
\hline & & $\#$ & $\%$ & $\#$ & $\#$ & $\#$ & $\%$ \\
\hline \multirow{10}{*}{ 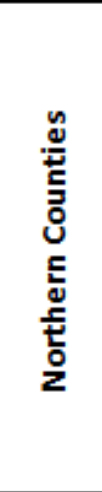 } & Bergen & 22,412 & $7.0 \%$ & 2,478 & 584 & 1,894 & $76.4 \%$ \\
\hline & Essex & 41,911 & $13.1 \%$ & 2,157 & 218 & 1,939 & $89.9 \%$ \\
\hline & Hunterdon & 31,060 & $9.7 \%$ & 1,942 & 172 & 1,770 & $91.1 \%$ \\
\hline & Middlesex & 23,157 & $7.2 \%$ & 2,127 & 309 & 1,818 & $85.5 \%$ \\
\hline & Monmonth & 29,233 & $9.1 \%$ & 2,299 & 227 & 2,072 & $90.1 \%$ \\
\hline & Morris & 23,666 & $7.4 \%$ & 967 & 165 & 802 & $82.9 \%$ \\
\hline & Somerset & 17,689 & $5.5 \%$ & 2,307 & 448 & 1,859 & $80.6 \%$ \\
\hline & Sussex & 20,346 & $6.3 \%$ & 452 & 51 & 401 & $88.7 \%$ \\
\hline & Warren & 18,627 & $5.8 \%$ & 469 & 47 & 422 & $90.0 \%$ \\
\hline & TOTAL NORTHERN & 228,101 & $71.1 \%$ & 15,198 & 2,221 & 12,977 & $85.4 \%$ \\
\hline \multirow{7}{*}{ 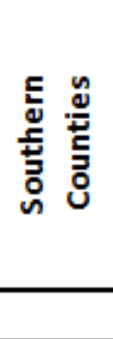 } & Burlington & 31,107 & $9.7 \%$ & 1,378 & 23 & 1,355 & $98.3 \%$ \\
\hline & Cape May & 4,936 & $1.5 \%$ & 228 & 3 & 225 & $98.7 \%$ \\
\hline & Cumberland & 14,093 & $4.4 \%$ & 788 & 2 & 786 & $99.7 \%$ \\
\hline & Gloucester & 28,431 & $8.9 \%$ & 1,553 & 4 & 1,549 & $99.7 \%$ \\
\hline & Salem & 14,155 & $4.4 \%$ & 1,412 & 1 & 1,411 & $99.9 \%$ \\
\hline & TOTAL SOUTHERN & 92,722 & $28.9 \%$ & 5,359 & 33 & 5,326 & $99.4 \%$ \\
\hline & TOTAL NEW JERSEY & 320,823 & $100 \%$ & 20,557 & 2,254 & 18,303 & $89.0 \%$ \\
\hline
\end{tabular}

This disparity is important to note as we examine trends in slavery and abolition, since manumission evolved much more quickly in the southern region of the state. ${ }^{9}$

Even among those who eventually experienced freedom from the 1804 Act, the notion of freedom in New Jersey was not always secure. Gigantino identifies cases of New Jersey Black people being sold back into slavery after their indentures should have been completed, including the case of a woman who was listed as free in the 1850 census but was sold back into slavery in

\footnotetext{
${ }^{9}$ This phenomenon remains true today, as $73 \%$ of New Jersey's population is found in the more urbanized northern counties of the state, according to 2019 population estimates.
} 
1856. ${ }^{10}$ In addition, "bounty hunters" ${ }^{11}$ were known to visit communities of Black people in search of anyone who might fit the description of an escapee. Of course, any Black person could be made to "fit the description," putting scores of free and freed Black people at risk, along with those who had escaped. So how did this term "First Emancipation" relate to New Jersey, given the lack of definitive action by the legislature in its 1804 and 1846 laws? Did any bona fide emancipation take place at all?

The regional variation in emancipation trends between northern and southern New Jersey had actually begun more than a decade before the 1804 gradual manumission act. ${ }^{12}$ As seen in Figure 2, the first U.S. census indicated that nearly two-thirds of Black people living in the southern counties of New Jersey in 1790 were classified as free, while only $10.9 \%$ in the northern counties were classified as free. The northern counties did not catch up with the southern counties

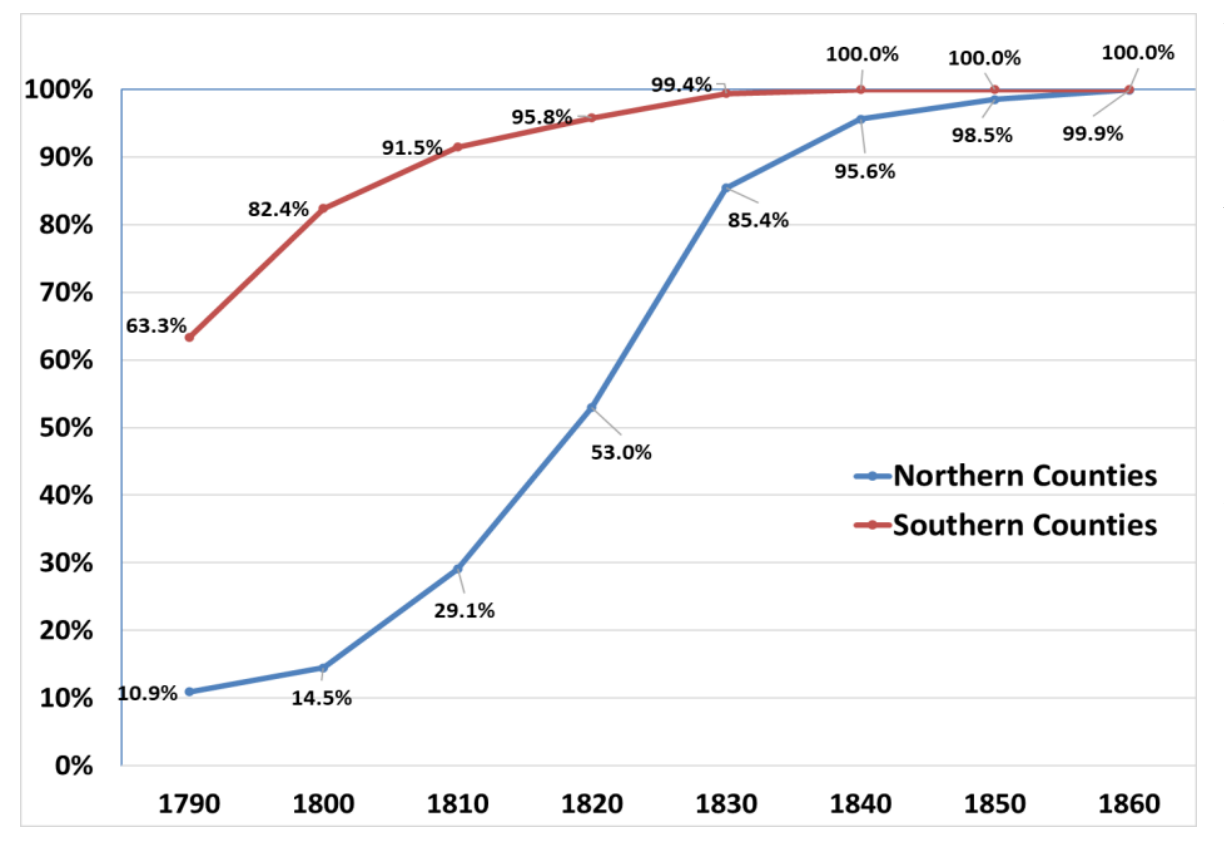

until 1850. On this basis, the "First Emancipation" began to take root in southern New Jersey decades earlier than in the northern region of the state.

Figure 2. Percent Free Black People by Region in Each Census

${ }^{10}$ James J. Gigantino. The Ragged Road to Abolition Slavery and Freedom in New Jersey, 1775-1865 (Philadelphia, University of Pennsylvania Press, 2015), 1.

${ }^{11}$ This term is used in lieu of slave catchers so as not to use terminology that gives credence to the institution of slavery.

${ }^{12}$ Guy Weston, “New Jersey, a State Divided on Freedom,” AAHGS, 2017:332. 
A number of factors account for this stark contrast. Most notably, Quaker influence was strongest in the southern counties. While many Quakers enslaved Black people before 1776, a long and passionate debate led to the conclusion that enslavers should play no role in the Society of Friends, because:

- Enslavement of Africans was incompatible with the Christian golden rule

- Liberty was the birthright of Blacks as well as Whites ${ }^{13}$

Quakers were leaders of advocacy to end slavery in New Jersey, petitioning the legislature to enact laws to abolish slavery as early as $1775 .{ }^{14}$ They finally succeeded with the passage of the 1804 legislation noted above. ${ }^{15}$ Even before this legislation was passed, Quakers led by example. By 1800, the residents of Burlington, Gloucester, and Salem Counties owned only $3 \%$ of the Black people still being held in slavery within New Jersey, whereas they comprised $23 \%$ of the state's population. ${ }^{16}$ Referring to the size and influence of the Quaker population in this region, nineteenth-century historian Henry Scofield Cooley called these "the three great Quaker counties." $" 17$

Some scholars ${ }^{18}$ question the Quakers' interest and commitment to abolition, asking how Quaker interest in the welfare of Black people can be genuine, in light of racist behavior. The

\footnotetext{
${ }^{13}$ Henry Scofield Cooley, A Study of Slavery in New Jersey (Baltimore: Johns Hopkins University Press, 1896) 1719.

${ }^{14}$ Wright, Afro-Americans in New Jersey, 22.

${ }^{15}$ Wright, Afro-Americans in New Jersey, 19.

${ }^{16}$ Craig Koedel. South Jersey Heritage: A Social, Economic, and Cultural History (Lanham: University Press of America, 1979).

${ }^{17}$ Henry Scofield Coley, A Study of Slavery in New Jersey, 31. Note: Camden and Atlantic Counties had not been created yet at this point.

${ }^{18}$ Donna McDaniel and Vanessa Julye, Fit for Freedom, Not for Friendship: Quakers, African Americans, and the Myth of Racial Justice (Philadelphia: Quaker Press, 2009); Graham Russell Hodges, Slavery and Freedom in the Rural North: African Americans in Monmouth County, New Jersey, 1665-1865 (Madison: Madison House, 1997).
} 
example of William Boen (1735-1824) also supports this viewpoint. ${ }^{19}$ Boen had learned about Quakerism from his Quaker enslaver, who frequently took him to Meeting for Worship while he was enslaved. Boen was impressed enough to petition the Mount Holly Monthly Meeting ${ }^{20}$ for membership on his wedding day at age 28 , and repeatedly petitioned throughout his life. He was refused over and over again, notwithstanding advocacy from John Woolman, the most influential Quaker abolitionist of the era. Finally, in 1814, when Boen was 79, he was admitted to the Mount Holly Meeting. In another case, Woolman recommended a Black man to be an Elder (likely Boen), and the Meeting responded that they would rather have no elder at all than to have a Black elder. ${ }^{21}$ The resistance to considering Black people as equals is obvious in this case. Clearly, some who advocated for abolition did not want Black people to be their peers.

The Quakers' motivation to manumit enslaved people and/or advocate against slavery has also been questioned. Did this occur based on self-interest in otherworldly salvation or guilty feelings rather than empathy toward those held in bondage $?^{22}$ Objectively speaking, issues like this are difficult to assess 200 years later because we don't know to what extent such attitudes should be generalized to the Society of Friends as a whole. We do know Quakers were unique among Christian groups in abolition efforts by having calls from leadership for members to manumit enslaved persons, with serious consequences for not doing so. ${ }^{23}$ Other Christian groups

\footnotetext{
${ }^{19}$ Anecdotes and Memoirs of William Boen, a Coloured Man, Who Lived and Died Near Mount Holly, New Jersey. Philadelphia: John Richards, 1834, https://docsouth.unc.edu/neh/boen/boen.html. Retrieved on October 12, 2020.

${ }^{20}$ In Quakerdom, "Monthly Meeting" and "Yearly Meeting" refer both to regional assemblies of Quakers, and the frequency of their business gatherings. A Yearly Meeting is a regional grouping that meets annually.

${ }^{21}$ William Cadbury, Negro Membership in the Society of Friends (Nether Providence: Pendle Hill, 1937).

${ }^{22}$ Graham Russel Hodges, Slavery and Freedom, 1997.

${ }^{23}$ Gigantino, 2015, Ragged Road, 71.
} 
involved in abolition were typically "non-conformist" factions of these denominations, without the influence to compel action from their entire denominations. ${ }^{24}$

Given the foregoing, what we can say more definitively are things like Black settlements in southern New Jersey tended to be near Quaker strongholds; ${ }^{25}$ Quakers had tangible participation in Black settlement such as selling land and providing mortgages, legal services to escaping people, and employment; ${ }^{26}$ and Quaker-dominant southern New Jersey was more favorable overall to abolition than the counties in the northern region of the state. ${ }^{27}$

The influence of Quakers in southern New Jersey in general, and Burlington County in particular, cannot be overstated. Philadelphia Yearly Meeting ${ }^{28}$ first met in Burlington in 1681. John Woolman, the influential Quaker abolitionist noted above, was from Mount Holly. Burlington County had the largest Quaker population in the region in Woolman's era. ${ }^{29}$

Wright points out that other factors also might have contributed to regional differences in the progress of abolition. ${ }^{30}$ He notes that about $75 \%$ of enslaved people were found in Bergen, Essex, Middlesex, Hunterdon, Somerset, and Monmouth Counties during this period. This is significant, since these counties tended to be more economically developed and had labor scarcities, thereby having economies that relied more on the labor of enslaved people. These areas

\footnotetext{
${ }^{24}$ John Coffey, "The Abolition of the Slave Trade: Christian Conscience and Political Action," Cambridge Papers, No. 15 (2006); Roger Anstey, ““'Slavery and The Protestant Ethic,"“ Historical Reflections, Vol. 6 (1979) 157-181.

${ }^{25}$ Christopher Barton, The Archaeology of Race and Class at Timbuctoo (Gainesville: University Press of Florida, in press).

${ }^{26}$ Christopher Barton. Identity and Improvisation: Archaeology at the African American Community of Timbuctoo, New Jersey. Dissertation submitted for PhD in anthropology, Temple University, 2014.

${ }^{27}$ Ernest Lyght, Path to Freedom: The Black Presence in New Jersey's Burlington County, 1659-1900 (Cherry Hill: E\&E Publishing House, 1978) 22; Giles Wright, Afro-Americans in New Jersey, 23.

${ }^{28}$ In Quakerdom, Yearly Meeting refers both to a geographic region and its annual assembly of members.

${ }^{29}$ John E. Pomfret, "West New Jersey: A Quaker Society 1675-1775," William and Mary Quarterly, Vol. 8, No. 4, 493-519.

${ }^{30}$ Wright, Afro-Americans in New Jersey, 28, 36.
} 
also had more German, Dutch, and non-Quaker settlers. The Dutch had historically "led introducing slaves in large numbers" under a proprietary regime that incentivized enslavement by offering acres of land for every enslaved person imported up to $1702 .^{31}$ This system would impact the number of enslaved persons associated with Dutch settlers in future decades.

\section{Timbuctoo: A Case Study in Antebellum Emancipation}

Timbuctoo, in Burlington County, is a Black settlement near Mount Holly that appeared on area maps as early as $1849 .{ }^{32}$ A review of extant deeds and other legal documents in the office of the Burlington county clerk found that the first land sales to Black people in what would later be called Timbuctoo occurred in September of $1826 .{ }^{33}$ Over the next three decades, the population grew sparingly, reaching about 125 by $1860 .{ }^{34}$ Timbuctoo residents included free Black people, as well as those escaping slavery. ${ }^{35}$

Precise population counts are difficult to determine, since white and Black populations are intermingled in the sequence of census enumerations. Therefore, it is difficult to isolate residents of Timbuctoo to count them separately. Interestingly, the sequence of census enumerations suggests populations in adjacent areas were not totally segregated by race. The U.S. census only counts "the Village of Timbuctoo" as a separate entity in 1880, enumerating 108 residents in 29 households. ${ }^{36}$ A January 1886 article from the Camden Post claims a population of over $600 .{ }^{37}$

\footnotetext{
31 Wright, Afro-Americans in New Jersey, 19.

${ }^{32}$ Rutgers University, Burlington County 1848, http://mapmaker.rutgers.edu/BURLINGTON_COUNTY/OldBurlington.html. Retrieved August 7, 2021.

${ }^{33}$ National Park Service, "Timbuctoo, Burlington County," Katherine Turton, New Jersey: National Park Service, 2008.

${ }^{34}$ Lyght, Path to Freedom, 40.

${ }^{35}$ Lyght, Path of Freedom, 38.

361880 U.S. Census; Timbuctoo, Burlington, New Jersey; Roll: 772; Family History Film: 1254772; Page: 296298B; Enumeration District: 022; Image: 0596, Ancestry.com, http://www.ancestry.com. Accessed December 15, 2014).

37 “A Jersey King,” Camden Post, January 16, 1886, page 3.
} 
Further research comparing land transactions to census records and vital records will provide helpful clarity to elucidate population trends more specifically.

Notwithstanding these limitations, the quantity of extant documentation of Timbuctoo history is remarkable. Most notably:

1. A collection of Timbuctoo deeds from the National Park Service spans more than 100 years, beginning in 1826, including transcriptions of nineteenth-century documents that were originally handwritten. ${ }^{38}$

2. Corporation records relevant to Timbuctoo also go back to 1826 , including at least three churches, two of which included cemeteries, as well as two schools and a benevolent association. $^{39}$

3. Area newspapers provide a surprising window into nineteenth-century Timbuctoo. Most notable is the New Jersey Mirror, which was a major regional publication for several decades, beginning in $1818 .^{40}$

4. Birth and death records are available through the New Jersey Births and Christenings Index ${ }^{41}$ and the New Jersey Deaths and Burials Index as early as the $1850 \mathrm{~s}^{42}$ This is particularly significant for African American genealogy, where such information is frequently dismissed as nonexistent. ${ }^{43}$

\footnotetext{
${ }^{38}$ National Park Service, Timbuctoo, Burlington County, 2008.

39 Ibid.

${ }^{40}$ Burlington County Library, New Jersey Mirror. https://www.bcls.lib.nj.us/.

${ }^{41}$ Guy Weston, "Finding Free African Americans During the Antebellum Period," National Genealogical Society, 41:1 (2015) 51.

42 Weston, "Finding Free African Americans," 51.

${ }^{43}$ Henry Louis Gates, In Search of Our Roots (New York: Crown Publishing Company, 2009), 419-420.
} 
Information contained in these sources goes a long way in providing details about antebellum Black life that frequently are not available.

Given information in the foregoing sources, at least some of the post-slavery progress of the south in the latter nineteenth century was already ongoing in some northern communities several decades earlier, particularly southern New Jersey and southeastern Pennsylvania, where Quaker influence was strong. Timbuctoo residents owned land, established institutions, registered corporate documents with the county clerk, and read obituaries of their rank-and-file citizens in the local newspaper. Timbuctoo must not have been unique in these achievements, given the quantities of antebellum free Blacks in urbanized areas such as Philadelphia, New York City, and Boston. Perhaps the uniqueness of Timbuctoo is the extent of extant documentation available for research, as detailed below.

\section{Land Ownership}

Figure 3 on the next page illustrates the earliest land transactions in Timbuctoo, providing a snapshot of the sequence of sales, the sellers, and the establishment of institutions (schools and churches). 
Figure 3. Map of Land Purchases in Timbuctoo

\section{Early Settlement in Timbuctoo, N.J.}

\section{Original Property Sellers}

$\square$ 1st-William Hilyard

$\square$ 2nd-Samuel Atkinson

3rd-Abigail Haywood

4th-Thomas Grissom Sr. \& Jr.

Peter Quire subdivided his lot in 1834

to help establish the African Union School

John Bruer subdivided his lot in 1841 to help establish the Schoolhouse \& Place of Divine Worship

1 Peter Quire, 1831

2 African Union School, 1834

3. Major Mitchel, 1830

[4. John Bruer, 1829

5 John Bruer, 1831

6 Schoolhouse \& Place of Divine Worship, 1841

7. David Parker, 1831

8 Samuel Parker, 1831

9 David Parker, 1826

10 Wardell Parker, 1826

11 Hezekiah Hall, 1826

12 George Wilmore, 1826 or earlier

13 Ezekiel Parker, 1826

14 Mary Hugs, 1838

15 Zion Wesleyan Methodist Episcopal

African Church (\& Cemetery), 1854

16. Joseph Hargrove, 1834

17. Henry Simmons, 1834

18 William Hill, 1839

19 Joseph Parker, 1833

20 David Parker, 1842

211 Levi Griffin, 1840

22. Gillis Parker, 1842

23 Joseph Hargrove, 1834

24 Alexander Armstrong, 1842

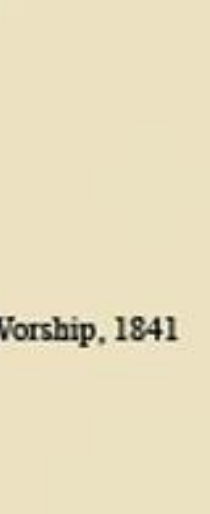


It is noteworthy that William Hilyard and Samuel Atkinson, who sold the majority of the acreage, were Quakers. Atkinson is identified in census records as a farmer, whereas Hilyard, who sold the first lots, was a farmer and also a businessman who owned nearby brickyards that employed some Timbuctoo residents. Both Atkinson and Hilyard were members of Rancocas Monthly Meeting. ${ }^{44}$ The Society of Friends maintains vast collections of genealogical and historical records that may include additional pertinent details about these men and their families, such as participation in abolition activities.

The names of women are rarely mentioned among extant documents describing the efforts of local whites that facilitated Timbuctoo's development, except to describe them as wives in reference to land sales. Abigail Bowne Haywood is a notable exception. Beginning in 1834, she and/or her estate subdivided her approximately two acres into eight parcels as small as one-tenth of an acre, sometimes selling at prices comparable to prices for lots of an acre or more a decade earlier. ${ }^{45}$ This surprisingly independent woman, whose 1863 gravestone bears her maiden name, ${ }^{46}$ was a socialite born in New York City, ${ }^{47}$ where slavery was abolished by gradual manumission in 1799. Her husband was a prominent judge named George Haywood, who was born in Virginia, ${ }^{48}$ where slavery did not end until the end of the Civil War. He was sympathetic to the "bounty hunters," who came to New Jersey at the behest of Southern enslavers in search of escapees. On more than one occasion, his rulings supported Southern enslavers, ${ }^{49}$ even while his wife's actions

\footnotetext{
${ }^{44}$ U.S. Quaker Meeting Records, 1681-1935, Database, https://www.ancestry.com/search/collections/2189/. Retrieved on August 11, 2021.

45 National Park Service, Timbuctoo, Burlington County, 2008.

${ }^{46}$ Find A Grave, Database, https://www.findagrave.com/memorial/78332685/abigail-haywood. Retrieved on August $11,2021$.

471860 United States Federal Census. Year: 1860; Census Place: Northampton, Burlington, New Jersey, page 546.

${ }^{48}$ Ibid.

${ }^{49}$ Dennis Rizzo. Parallel Communities: The Underground Railroad in South Jersey (Charleston: The History Press, 2008).
} 
supported their resettlement in New Jersey. Interestingly, the 1860 census lists her estate as having a value of $\$ 20,000$, whereas his was worth $\$ 200 .{ }^{50}$ Further research can examine Abigail Bowne Haywood's activities in this context.

No remarkable details were identified about Thomas Grissom Jr. and Sr., other than Thomas Jr.'s military service during the Civil War.

\section{First Five Buyers}

In September of 1826, Ezekiel Parker, David Parker, Wardell Parker, and Hezekiah Hall purchased their parcels of land from William Hilyard, ranging in size from 0.5 to 1.5 acres. The prices ranged from $\$ 8.33$ to $\$ 24.05$ "paid in hand," in other words, paid in cash. ${ }^{51}$ Who were these men and how did it come about that they would all buy parcels from the same seller in the same month?

Ezekiel Parker seems to disappear in subsequent records. By contrast, Hezekiah Hall, Wardell Parker, and David Parker are all visible in subsequent decades through real estate transactions, other legal documents, membership on boards of directors, and newspaper reports. The fifth recorded sale did not occur until 1829, when Samuel Atkinson sold one acre to John Bruer for $\$ 30$.

An overview of these buyers provides a snapshot of the earliest settlement as follows:

\section{Hezekiah Hall}

Hezekiah Hall was a 35-year-old Mount Holly resident when he purchased his land parcel in Timbuctoo. His substantial obituary provides details about his earlier life that aren't readily

\footnotetext{
${ }^{50} 1860$ United States Federal Census, Year: 1860; Census Place: Northampton, Burlington, New Jersey, page 546.

${ }^{51}$ National Park Service, Timbuctoo, Burlington County, 2008.
} 
available for his peers. ${ }^{52}$ At his death in 1851, the New Jersey Mirror reports he had escaped bondage in Maryland in 1814 , having been enslaved by Charles Carroll of Carrollton, ${ }^{53}$ and subsequently settled in the area around 1824. Hall is listed as a trustee on the deed for the African Union School in 1834, as well as "a schoolhouse and place for divine worship," in 1841 . The 1850 census, which was the first to record additional personal details such as occupation, says he was a laborer. His will makes reference to rents and profits from real estate holdings that his wife was to be responsible for, and the inventory of his estate includes an $\$ 84.25$ balance of rent due, bonds, and mortgage interest. To put $\$ 84.25$ in perspective, entire parcels of land were selling for less than half that much in this era. Hall left his movable estate and the management of his business affairs to his wife, while his real estate was devised to his children.

\section{Wardell Parker}

Wardell Parker and David Parker were both born in Maryland but have different fathers' names reported in the New Jersey Deaths and Burial's Index. ${ }^{54}$ On that basis, we don't presume they were brothers, as some researchers have suggested, but it does seem plausible that the three Parkers were related, given their arrival in the same month to purchase land in close proximity from the same seller. Roughly 43-year-old Wardell was listed as a Mount Holly resident in his 1826 Timbuctoo land purchase, and he was already living in Mount Holly long enough to have been a trustee on the deed documenting a land purchase by Mount Moriah AME church six months

\footnotetext{
52 “Obituaries,” New Jersey Mirror, 27 February 1851, p. 3, col. 2; Indexed Transcription, Burlington County Library System, https://www.bcls.lib.nj.us/.

${ }^{53}$ Charles Carroll was the first elected senator of Maryland and a signer of the Declaration of Independence. 54 “New Jersey Deaths and Burials Index, 1798-1971," Database, https://www.ancestry.com/search/collections/2539/. Retrieved on August 10, 2021.
} 
earlier, in March $1826 .{ }^{55}$ Mount Moriah is located about 1.5 miles from Timbuctoo, near Mount Holly. Ernest Lyght ${ }^{56}$ indicates that Wardell Parker was a preacher in addition to being a trustee and "provided a source of stability" for the young congregation. Similarly, his New Jersey Mirror obituary says he was "for many years, a preacher among the colored people of the neighborhood. ${ }^{" 57}$ Cooperation between churches was evident, as Wardell Parker served as a witness on the certificate of incorporation for Zion Wesleyan Methodist Episcopal African Church in Timbuctoo in 1854. Wardell Parker died in 1860. No will was found for him. ${ }^{58}$

\section{David Parker}

David Parker was a resident of Evesham at the time of his first land purchase in Timbuctoo, in 1826 , when he would have been about 25 years old. He was by far the most prominent Timbuctoo resident for decades, and he outlived his fellow early settlers by several years. He also outlived two wives. In 1871, when he would have been about 70 years old, David married 36-yearold Clarissa Cole of Philadelphia "after a long and tedious courtship," Jersey Mirror.

David Parker was also associated with multiple land transactions, and likely was the most financially successful of his peers. It is noteworthy that the only three remaining civilian grave

\footnotetext{
${ }^{55}$ Burlington County, New Jersey, Deeds, T2:64 Larner Waterman and wife to Perry Gibson, Wardell Parker and others, Trustees of African Methodist Episcop. Church, 14 March 1826; Burlington County Clerk's Office, Mount Holly.

${ }^{56}$ Lyght, Path of Freedom, 65.

57 “Obituaries," New Jersey Mirror, 26 April 1860, p. 3, col. 3; Indexed Transcription, Burlington County Library System, https://www.bcls.lib.nj.us/.

58 This research is ongoing, since indexing handwritten legal documents is sometimes complicated by legibility of handwriting.

59 “Marriages," New Jersey Mirror, 15 November 1871, p. 2, col. 5; Indexed Transcription, Burlington County Library System, https://www.bcls.lib.nj.us/.
} 
markers in the Timbuctoo Cemetery are Eliza Parker, Matilda Parker, and Frisby Parker ${ }^{60}$ Eliza and Matilda were his first two wives and Frisby was his son. Having stone grave markers is an indicator of financial resources, in an era where ordinary citizens frequently had wooden markers that did not survive time. David Parker was the president of the Beneficial Society of the United Sons of Daughters of Timbuctoo and Vicinity, ${ }^{61}$ and the first listed trustee on the deed and certificate of incorporation for the Zion Wesleyan Methodist Episcopal African Church of Timbuctoo. ${ }^{62}$

There are multiple references to David Parker in news articles in the New Jersey Mirror, as well as the Camden Post and the Philadelphia Inquirer, sometimes referring to him as "King" David. For example, his 1877 New Jersey Mirror obituary says "King David, as he had been known in other years, was possessed of more than ordinary intelligence and a determined will, which made him a natural leader among his people so long as his physical strength lasted, and he was generally at the head of any movement among them." ${ }^{63}$ A profile of Timbuctoo under the title "The Villages Among Us" in 1855 says, "David Parker is the King of the place, and ever since the imperial crown was placed upon his woolly head, his word has been considered Law and Gospel by the whole tribe." ${ }^{\prime 64}$ An 1860 story about an unsuccessful attempt to kidnap formerly enslaved Perry Simmons says King David Parker “commands” Timbuctoo warriors that came to Simmons’s

\footnotetext{
${ }^{60}$ Timbuctoo Historical Society, Zion Wesleyan Methodist Episcopal African Church and Cemetery, www.timbuctoonj.com/cemetery.

${ }^{61}$ Burlington County, New Jersey, Deeds, A:85, Beneficial Society of the Sons and Daughters of Timbuctoo, 15 March 1856; Burlington County Clerk's Office, Mount Holly. Corporation certificates were kept in deed books. ${ }^{62}$ Burlington County, New Jersey, Deeds, A:77, Zion Wesleyan Methodist Episcopal African Church, 23 December 1854; Burlington County Clerk's Office, Mount Holly.

63 “Obituaries," New Jersey Mirror, 28 June 1877. Transcribed from Microfilm on September 21, 2017.

64 “The Villages Among Us,” New Jersey Mirror, June 21, 1855. Transcribed from Microfilm on June 2, 2018.
} 
defense. ${ }^{65}$ Future research will seek to clarify the meaning of the repeated use of the word "King," and Parker's role as a community leader.

Sadly, probate records indicate that David Parker's estate was insolvent at the time of his death. On June 10, 1879, an order was issued to liquidate his assets for payment of outstanding debts. $^{66}$

\section{John Bruer}

John Bruer made the fifth recorded land purchase in December of 1829 . He was about 32 years old and already a resident of Northampton Township at this time. Since he died in 1843, before the U.S. census first provided household details in 1850, there is no information regarding his reported place of birth, or the other household details in 1830 and 1840. However, family oral history ${ }^{67}$ indicates he was Dutch. Since he is listed as a "free colored person" in the 1830 and 1840 censuses, and has a Dutch name, we conclude he may have been biracial with a Dutch father. ${ }^{68}$ Later records anglicize the spelling of his name to $B-r-e-w-e-r$.

Bruer is listed as a trustee on a corporation filing for Mount Moriah AME Church in 1840. This church had purchased a parcel of land to build its first sanctuary in 1826 about a mile and a half from Timbuctoo. However, in 1841, Bruer subdivided his lot to provide land for a "schoolhouse and place of divine worship." ${ }^{69}$ Since the location of this schoolhouse is about 200

\footnotetext{
65 "Excitement at Timbuctoo, the Battle of Pine Swamp: Invaders forced to Retreat," New Jersey Mirror, 6 December 1860. Transcribed from microfilm on March 21, 2017.

${ }^{66}$ Burlington County, New Jersey, Book of Wills OC:179, Estate of David Parker, June 10, 1879; Burlington County Surrogates Office, Mount Holly.

${ }^{67}$ Bruer's wife was this author's fourth great-grandmother, and several of his personal documents remain in her descendants' possession today.

${ }^{68}$ It is also noteworthy the Dutch settlers were prevalent in the northern region of the state during this period.

${ }^{69}$ Burlington County, New Jersey, Deeds, A4:421 and A4:422, 14 October 1841; Burlington County Clerk's Office, Mount Holly. This was an unusual transaction in which John Bruer sold a lot to Amos Bullock, who resold it to the school/church trustees on the same day. Bruer was one of the trustees.
} 
feet from the African Union School, established in 1834, Bruer's action here raises questions about the disposition of the first schoolhouse, which is known to exist decades later. An unpublished manuscript entitled History of Mount Holly, $N J,{ }^{70}$ available from the Burlington County Library, references a "meeting house" in Timbuctoo that was set on fire and burned in May of 1841 without further detail. This information has fueled speculation as to whether the meetinghouse was actually Timbuctoo's African Union School, necessitating a second school building for some period of time.

Figure 4. Close Proximity of Schools in Timbuctoo

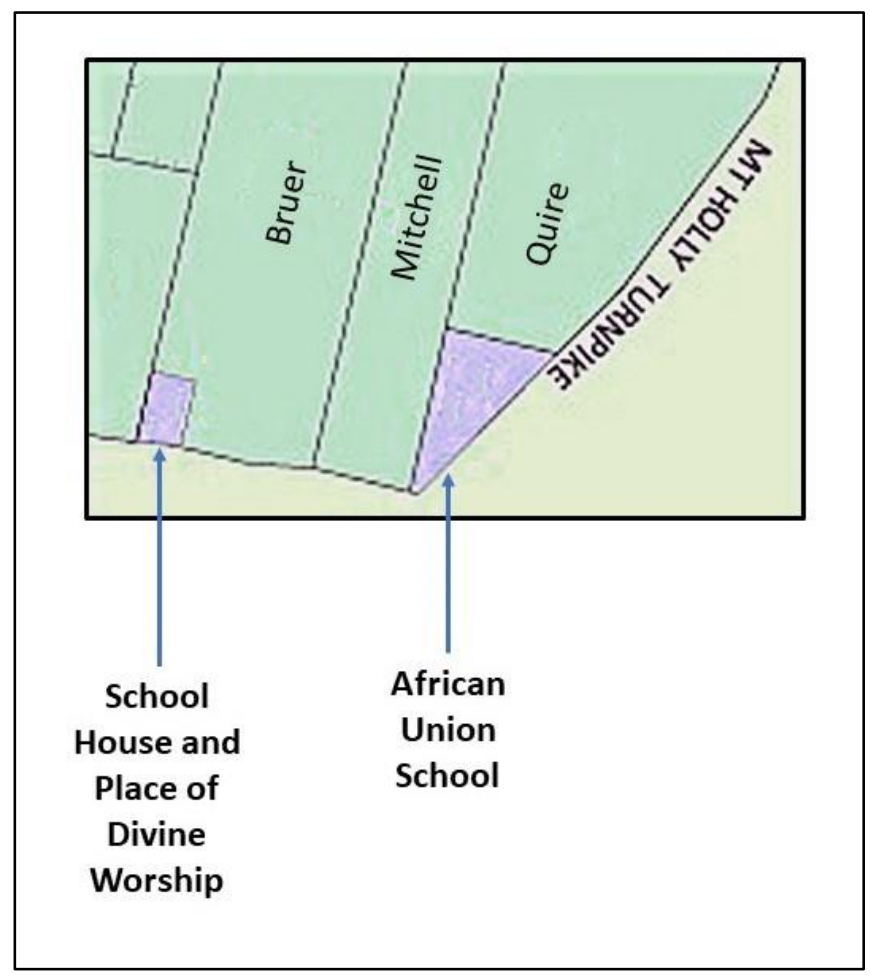

Bruer's 1842 will devises his premises "excepting the schoolhouse lot," to his wife, Ann Bruer. After her death, his real and personal estate is devised to her daughter, Sarah Barnes, and

\footnotetext{
${ }^{70}$ Zachariah Reed. History of Mount Holly, NJ (Unpublished manuscript available from the Burlington County
} Library, 1859). 
her "lawful issue," meaning Sarah's descendants."71 Bruer's wife and her daughter were both born in Pennsylvania, where gradual manumission of enslaved persons began in 1780, 24 years earlier than New Jersey's 1804 law.

Since the author of this article is also the lawful issue of Sarah Barnes, ${ }^{72}$ more is known about Ann's and Sarah's lives after John Bruer's death. For example, in 1845, Ann and Sarah, along with Sarah's husband, Lambert Giles, obtained a mortgage against their property from Jonathan Hilyard. Jonathan was from the same Hilyard family who sold the first Timbuctoo parcels in 1826. The amount of the mortgage is $\$ 155.00$. The original indenture of mortgage, still in the possession of Sarah's lawful issue today, has handwritten receipts on the back of annual payments in amounts initially ranging from about $\$ 2.00-\$ 7.00$ each year. An 1876 entry reads "received of John Giles, 2000 bricks @ $\$ 12.00$ a thousand to pay the interest on the within bond for 1875 and 1876." While this entry initially elicited visions of an ancestor arriving at the Hilyard home with a wagonload of bricks, subsequent knowledge that the Hilyard family operated a brick-making business provides a more plausible explanation. Some Timbuctoo residents were employed at Hilyard brickyards. It is likely that John Giles and his brothers had to make 2,000 bricks at work and paid this debt with their labor in lieu of receiving wages. Their father, Lambert Giles, had died in 1875 . No payment was recorded that year, possibly due to the hardship created by Lambert's unexpected death. ${ }^{73}$ An excerpt of the payment record is below in Figure 5.

\footnotetext{
71 "Lawful issue" is a legal term that means all of a person's children or other lineal descendants such as grandchildren and great-grandchildren. The term does not include all heirs, but only the direct bloodline. ${ }^{72}$ Sarah Barnes is this author's third great-grandmother.

${ }^{73}$ On April 22, 1875, the New Jersey Mirror reported that Lambert died of a likely epileptic seizure while walking home from work.
} 
Figure 5. Payment Record for Mortgage to John Bruer's Heirs

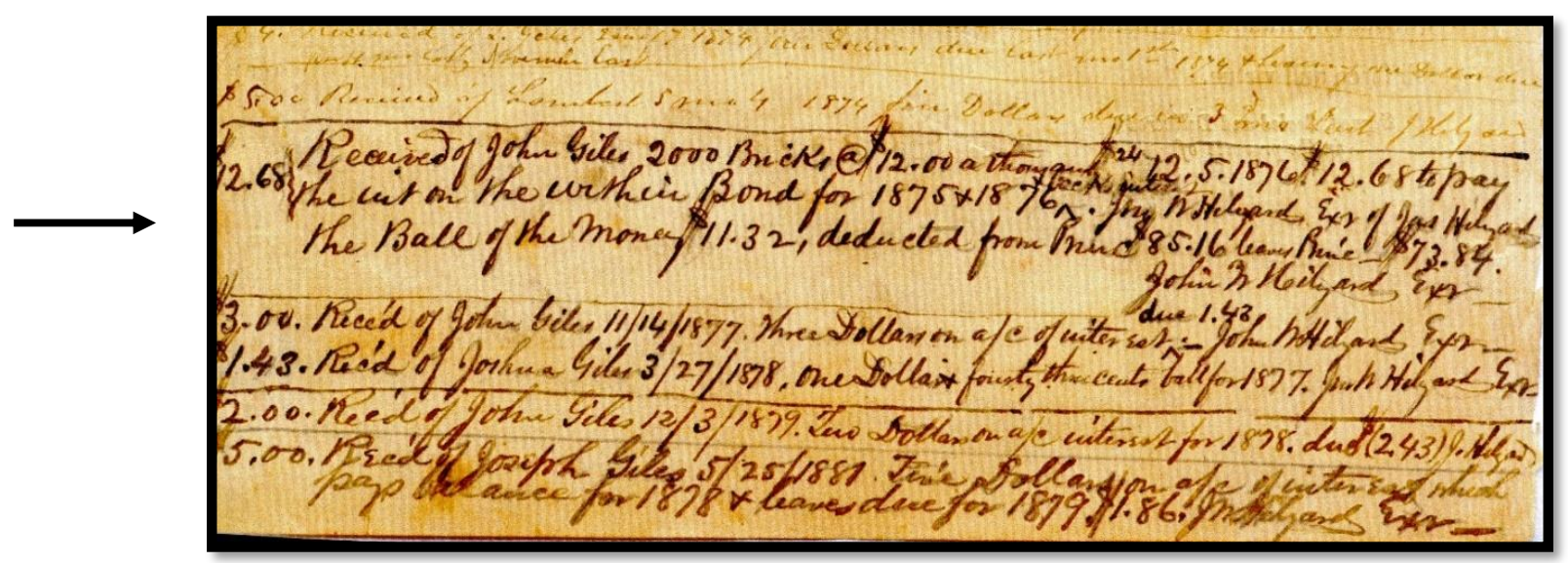

During the first two decades of settlement in Timbuctoo, about 25 transactions are recorded, including two schools and two churches. ${ }^{74}$ The land area represented in these transactions, comprising about 15 acres, would become the core settlement area of Timbuctoo, and it remains so today.

\section{Research Potential of Deeds with Census and Vital Records}

Although some errors and omissions have been found in the aforementioned deed collection, which was assembled prior to the advent of digitized historic records, having 100 years of deeds in a single PDF document ${ }^{75}$ presents a unique opportunity to understand population growth and decline, and other characteristics. Even though deeds will not capture rental occupants, census records, along with information from the New Jersey Births and Christenings Index, and the New Jersey Deaths and Burials Index, can facilitate the estimation of population trends. Beginning in 1850, the census reported the exact age, occupation, value of real estate, place of birth, literacy, and other variables. Although this information is subject to the limits of self-

\footnotetext{
${ }^{74}$ National Park Service, Timbuctoo, Burlington County, 2008.

75 Ibid.
} 
reporting and enumerator errors, it can provide useful insight into population characteristics, nevertheless.

\section{Corporation Documents}

Perhaps since the New Jersey legislature did not specifically provide for incorporation of churches and charitable organizations until the 1850s, early deeds for these entities contained corporation information, such as an organizational mission and some rules of operation. Changes in the 1850 s are evident by the 1856 certificate of incorporation of the Beneficial Society of the United Sons and Daughters of Timbuctoo and Vicinity, ${ }^{76}$ which begins by saying, "Whereas the Legislature of the State of New Jersey did by an act entitled An Act to Incorporate Benevolent and Charitable organizations, approved March 9, 1853," and goes on to describe how the act provides authority for the Beneficial Society to incorporate. Similarly, the 1854 certificate of incorporation of the Zion Wesleyan Methodist Episcopal African Church $^{77}$ begins with, "Whereas the religious society of colored persons accustomed to worship in the church or meeting house at Timbuctoo . . . being desirous of availing themselves of the act entitled An Act to Incorporate Trustees of Religious Societies, and the Supplements thereto ..." and is followed by discussion of the church having met the requirements to incorporate under the provisions of the act.

Documentation describing the mission and activities of this specific beneficial society was not identified. However, mutual-aid societies of this type were common in communities of free Black people during this period, typically by establishing a fund that members contributed to that provided support to the sick, elderly, or otherwise needy in the community. Much more

\footnotetext{
${ }^{76}$ Burlington County, New Jersey, Deeds, A:85. Beneficial Society of the United Sons and Daughters of Timbuctoo and Vicinity, 14 March 1856; Burlington County Clerk's Office, Mount Holly.

${ }^{77}$ Burlington County, New Jersey, Deeds, A:77. Trustees of the Zion Wesleyan ME African Church - Timbuctoo, 23 December 1854; Burlington County Clerk's Office, Mount Holly.
} 
information is available about the Zion Wesleyan Methodist Episcopal African Church, which had greater durability as a more tangible institution affiliated with a national body.

The deed for the Zion Wesleyan Methodist Episcopal African Church is dated 1854. In addition to the requisite details of buyers, sellers, price, and legal description, it says that for a price of $\$ 300$ :

... the said lot of land, hereditaments, and premises hereby granted and released ... unto the said Trustees of Zion Wesleyan Methodist Episcopal African Church and their successors . . . to be used as a place of religious worship, according to the form of government and discipline of the African Methodist Episcopal Zion Church in America, and as a place for the burial of the dead, of such as are in connection with said church, or the descendants thereof, (and such others as the majority of the Trustees for the time being may permit) forever.

This deed tells us this church was an AME Zion church, and the cemetery was established by this AME Zion Church for use of its members, associates, and others determined by the church's trustees at least seven years before the Civil War. This became a critical point of clarification recently when a well-meaning local historical society installed an expensive marker renaming the cemetery as the Timbuctoo Civil War Memorial Cemetery. This was a very logical error, as the cemetery had not been publicly affiliated with the church since the local congregation dissolved early in the twentieth century. Moreover, 8 of the 11 remaining gravestones are United States Colored Troops (USCT) who fought in the Civil War. The deed language suggests the USCT are buried in the cemetery because of their affiliation with the church, not because it's a military cemetery. In addition, ground-penetrating radar conducted in 2009 found at least 59 unmarked graves.

The disparity in grave markers is not surprising, since wooden grave markers were common among ordinary citizens during the period of these burials. These would not survive time. 
By contrast, USCT received stone grave markers as a benefit of military service and were therefore much less likely to have unmarked graves.

Acknowledgment of the AME Zion origins of the cemetery is critical, in light of the role of the AME Zion Church in Black communities during the antebellum and postbellum periods. Put simply, the church concerned itself with the "soul of individuals and the soul of the community." Since the Black community was one where the vast majority was held in bondage and exploited for the financial gain of enslavers, this denomination had a substantial role in the anti-slavery movement. It became known as the Freedom Church as a result. ${ }^{78}$ Given this mission, this church would have certainly played a role in anti-slavery efforts and the Underground Railroad in Timbuctoo. In a book titled The Geography of Resistance ${ }^{79}$ Cheryl LaRoche discusses how mapping Black settlements "visually clarifies and exposes the relationship between African American churches, settlements, and historic Underground Railroad routes," noting that most Black settlements had churches that were active on the Underground Railroad. Although LaRoche specifies AME churches, national AME Zion historical documents are clear in identifying the denomination's priorities in this regard. Erasure of the cemetery's original name, albeit inadvertent, detracts from potential inquiry into this aspect of Timbuctoo's history. It is noteworthy

\footnotetext{
${ }^{78}$ David Henry Bradley. A History of the A. M. E. Zion Church, Part 1: 1796-1872 (Eugene: Wipf and Stock Publishers, 2019).

${ }^{79}$ Cheryl LaRoche, Free Black Communities and the Underground Railroad: The Geography of Resistance (Urbana, University of Chicago Press, 2014), 140-143.
} 
that renowned nineteenth-century leaders like Harriet Tubman, ${ }^{80}$ Sojourner Truth, ${ }^{81}$ and Frederick Douglass $^{82}$ were members of the AME Zion Church.

\section{Research Potential of Church Documents}

These documents have already contributed substantively to preservation and community education regarding Timbuctoo. Since the local congregation that established the cemetery dissolved more than 100 years ago and the last marked interment was in 1922, the true affiliation of the cemetery was not widely known until the 1854 handwritten deed was transcribed in 2017. The county clerk's designation of the legal owner was simply "Colored Cemetery," using terminology that might have been deemed appropriate 50 or more years ago. The oldest gravestone is dated 1847, seven years earlier than the certificate of incorporation. The history regarding incorporating charitable organizations explains that the incorporation date and the founding date can be years, even decades apart in this era. Yet the oldest gravestone also precedes the deed by seven years, which could mean the 1845 purchaser of the church and cemetery parcel made it available for worship and burial purposes until the church was in a position to buy it. The 1847 gravestone of Eliza Parker, wife of David Parker, who was an officer of the church and Timbuctoo's most prominent citizen, raises further questions, as one would expect the gravestone of such a prominent member to be in a "legitimate" place. In any event, these documents will continue to be useful as research continues.

\footnotetext{
80 "Kristen T. Oertel, Harriet Tubman: Slavery, the Civil War, and Civil Rights in the 19th Century (New York: Routledge, 2016), 95.

${ }^{81}$ Washington, Margaret. "“From Motives of Delicacy': Sexuality and Morality in the Narratives of Sojourner Truth and Harriet Jacobs," The Journal of African American History, 92, no. 1 (2007), 59.

${ }^{82}$ Lenwood G Davis, "Frederick Douglas as a Preacher, and One of His Last, Most Significant Letters," The Journal of African American History, 66: 2, 140.
} 


\section{African Union School}

The deed ${ }^{83}$ for the purchase of a parcel to build the African Union School in Timbuctoo in 1834 is also intriguing. In addition to the requisite indications of the sellers, buyers, price, and legal description of the premises, it says:

Whereas, in the Settlement of Tombuctoo ${ }^{84} \ldots$ and in the vicinity thereof, there are many People of Colour (so called), who seem sensible of the advantages of a suitable school education and are destitute for a house for that purpose. And the said Peter Quire, and Maria, his wife in consideration of the premises, and the affection they bear to the People of Colour, and the desire they have, to promote their true and best interests, are minded to settle, give, grant and convey ... said premises to the uses and intents hereinafter pointed out and described.

This deed also stipulated that future board members had to be "People of Color" who lived within 10 miles of the premises. This clause is among the most surprising findings in extant documents related to Timbuctoo, because it suggests a level of recognition that runs counter to common perceptions about limitations antebellum Black people were subjected to. This characterization is not meant to suggest a high level of respect and deference afforded to this school as would have been afforded to a white institution. However, the document was filed in the office of the county clerk in an era most known for criminalizing efforts to educate Blacks and controlling, if not impeding, any community organizing effort. Further research will seek to explore how this "recognition" and perceived autonomy may have actually manifested in this and other circumstances.

\footnotetext{
${ }^{83}$ Burlington County, New Jersey, Deeds, G3:389, Peter Quire to Edward Giles, et al (January 4, 1834), Burlington County Clerk's Office, Mount Holly.

${ }^{84}$ Earliest references to Timbuctoo in New Jersey used variations of the French spelling Tombouctou. "Timbuctoo" is "Tombouctou" anglicized.
} 
Figure 5. African Union School Deed Excerpt

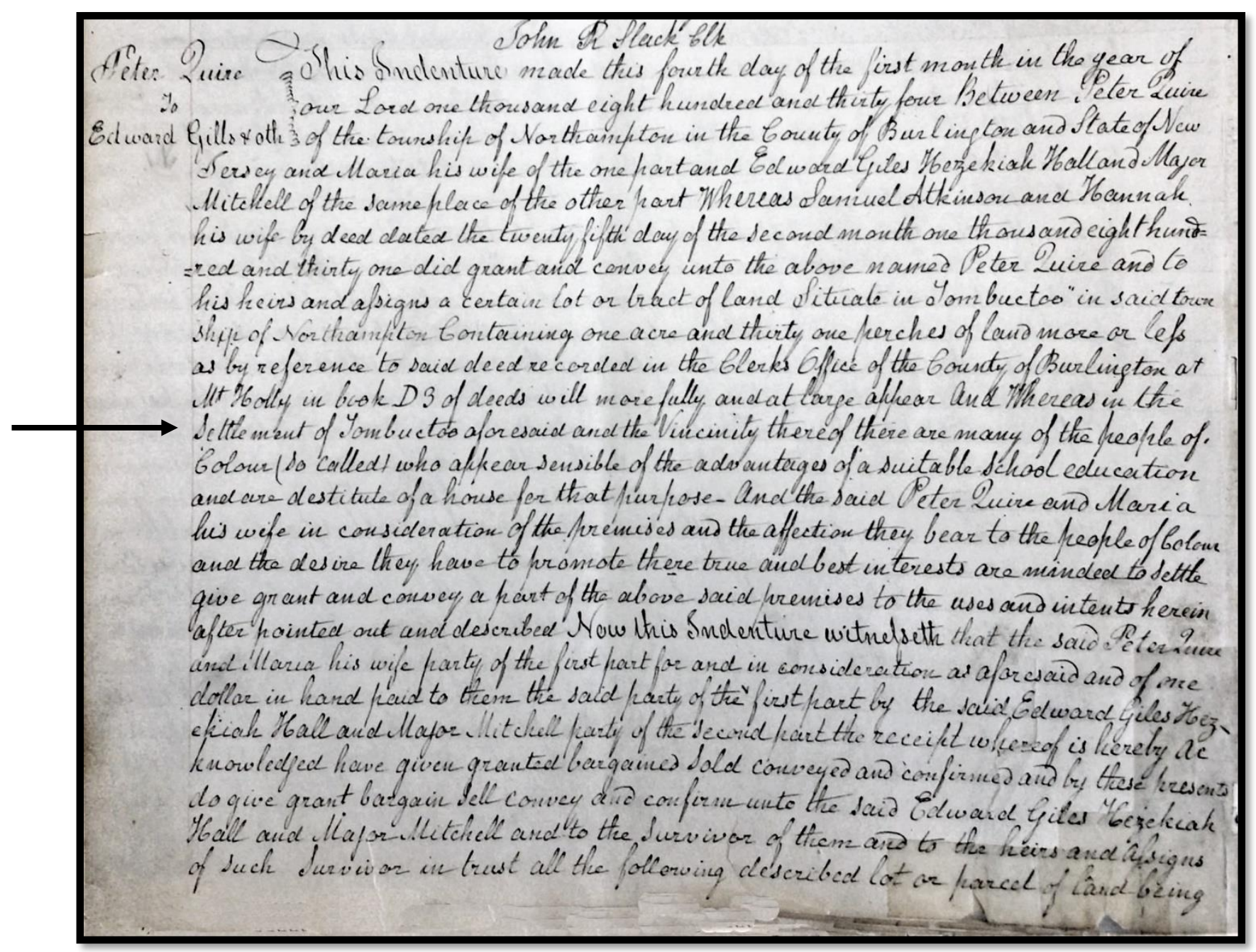

While the language "the affection they bear for the people of color" seems to imply that Peter and Maria were white people contributing to the Black community, they were actually Black landowners who subdivided the lot they purchased three years earlier for this benevolent purpose.

The location of the schoolhouse on a prominent corner lot facing what would become the

Mount Holly Turnpike also raises questions about how much Timbuctoo residents felt the need to hide for safety. This may not be so surprising, in the context of 1830s Burlington County: Just 23 Black Burlington County residents were counted as enslaved in the 1830 census, and the school's 
trustees declared in this deed essentially that it was a school for "people of color" and board membership would be limited to "people of color." Notwithstanding the danger of "kidnappers" working on behalf of Southern enslavers, the discrimination and challenges faced by Timbuctoo residents, and flagrant disregard of anti-slavery legislation documented by Gigantino and others, enslaved Black people were "officially" a rare phenomenon at this point in southern New Jersey. Black people were seeking to organize as they saw fit. This deed suggests they did so with some modicum of accomplishment. ${ }^{85}$ On the other hand, the unspecified "meeting house" fire in 1841 referenced previously may indicate that the school was burned down seven years later and subsequently rebuilt. Clearly, Timbuctoo residents faced daunting obstacles, even as they persisted in seeking freedom, education, and self-determination.

Use of the word African in the school's name should be noted. This was an era when the most prominent national institutions had names like African Methodist Episcopal Church, African Methodist Episcopal Zion Church, Free African Society, etc. It should not be a surprise to see this recognition at the local level as well. Use of the term "People of Color" in antebellum African American history is intriguing, as this term tends to be associated with recent time periods.

\section{Newspapers}

Prior to the advent of Newspapers.com and other efforts to index and digitize nineteenthcentury newspapers, the most accessible newspaper references about Timbuctoo came from the New Jersey Mirror, ${ }^{86}$ published from 1818 until 1947. This paper is partially indexed, ${ }^{87}$ with transcriptions available on the Burlington County Library website.

\footnotetext{
${ }^{86}$ Burlington County Library, New Jersey Mirror Index, https://www.bcls.lib.nj.us/.

${ }^{87}$ The specific extent of indexing could not be obtained from inquiry from current library staff, i.e., a range of years or percent completeness.
} 
Over its 130 years of publication beginning in $1818,{ }^{88}$ the New Jersey Mirror recorded the history of Burlington County in detail. Death reports and obituaries of Black people appeared together with reports of whites, and frequently paid very flattering comments. The earliest identified Black obituary is from 1824, but they appear more frequently beginning in the 1850s. Coverage of issues of interest to Blacks was frequently positive. For example, a story about an 1860 failed attempt to capture a Black man near Timbuctoo who previously escaped slavery, used words like "invaders" and "kidnappers" to refer to the captors, and ultimately criticizes the "failed attempt" and its actors. That's not to say there weren't pejorative and racist references in other places. An 1858 story about a conflict in Timbuctoo is entitled "Trouble Among the Darkies," even as the article purports an objective review of facts.

Overall, the depiction of Blacks in the New Jersey Mirror provides a unique contemporaneous window into antebellum life in a free Black community. In addition, common assumptions, such as the idea that Blacks cannot find useful and positive information for our genealogical research in antebellum newspapers published by white people for a presumed white readership, are challenged by the abundance of information found here.

The Mount Holly Herald was published from 1850 to 1942 and should have a quantity of pertinent information similar to the New Jersey Mirror. However, its index is restricted to limited vital events; thus, most research in this publication must be done via microfilm.

The extent of coverage of Timbuctoo issues in nonlocal newspapers should also be noted. Searching "Timbuctoo" and related person or event search terms on Newspapers.com found coverage in the Camden Post and the Philadelphia Inquirer for example, in many cases indicating

\footnotetext{
${ }^{88}$ Originally published as the Burlington Mirror.
} 
Timbuctoo as a known place far outside its immediate vicinity. Other publications with Timbuctoo coverage included the Monmouth Democrat, published in Freehold from 1854-1942; the Morning Call, published in Patterson from 1889-1969; the Newark Evening News, published from 18831972; and several others.

These full text articles provide perspectives of people and events as they are depicted in publications of their era:

- $\quad$ Hezekiah Hall New Jersey Mirror. February 27, 1851. Page 3, column 2

- $\quad$ Lambert Giles New Jersey Mirror. April 22, 1875. Page 3, column 1

- David Parker New Jersey Mirror. June 28, 1877. Page 3, column 1

- Trouble Among the Darkies New Jersey Mirror. Page 3, column 1

- $\quad$ The Battle of Pine Swamp New Jersey Mirror. December 6, 1860

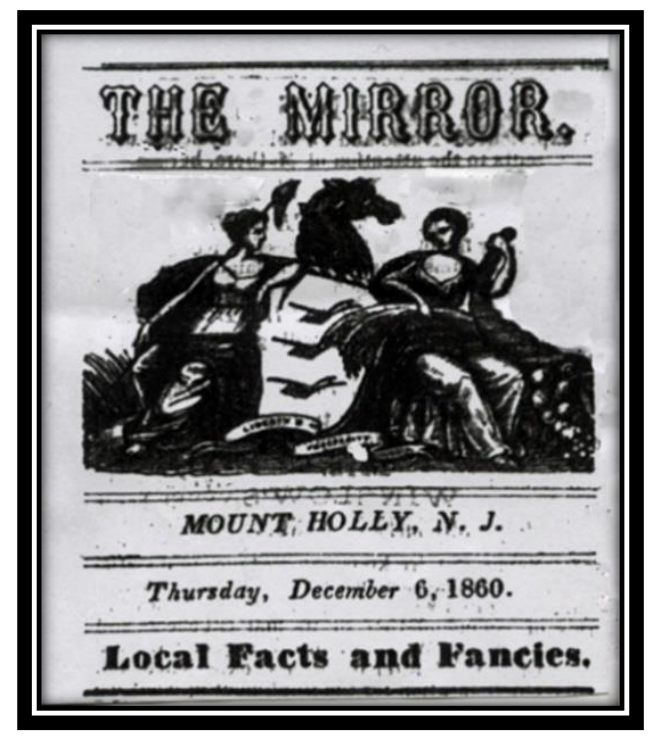

\section{Research Potential of Newspapers}

Newspapers have provided coveted information about ordinary residents in Timbuctoo, including basic information about birth and death dates, occupation, civic participation, and reputation, among other details. Obituaries in particular can be a rich source of information for antebellum Black genealogical research, where such information is frequently lacking for all but the renowned figures of African American history. However, the quantity of detailed obituaries is limited among indexed New Jersey Mirror articles. For example, the obituary of David Parker, arguably Timbuctoo's most prominent citizen in his era, was not indexed and had to be searched 
on microfilm and transcribed. Further research on microfilm of the New Jersey Mirror and the Mount Holly Herald can be expected to produce additional obituaries and death reports.

In addition, events in Timbuctoo, including a story about a conflict that uses the pejorative term "Darkies," civic and social events, and an infamous failed attempt to capture a formerly enslaved person provide unusual firsthand accounts of everyday life that can be insightful, in spite of the biases they may contain. The 1,100-word account of the "Battle of Pine Swamp" seems unrivaled in its detail and is a victorious outcome among news reports of confrontations between "bounty hunters" and escapees seeking freedom. ${ }^{89}$ Further research will seek to identify other stories similar to these, both in nearby communities and other areas of the Northeast and Midwest with substantial free Black populations.

\section{Vital Records}

The New Jersey Births and Christenings Index and the New Jersey Deaths and Burials Index are two additional resources that provide information about Timbuctoo of particular interest to genealogical researchers. Information about Timbuctoo residents has been found in these sources as early as the $1850 \mathrm{~s} .{ }^{90}$ This is particularly remarkable since vital records are not uniformly available in the United States until the 1910s. For Black people in particular, nineteenth-century vital records are a virtual gold mine, since the majority of the antebellum Black populations had

\footnotetext{
89 "The Christiana Riot," a successful armed resistance by formerly enslaved and free Black people seeking to prevent capture of escapees from Maryland in 1851 in Christiana, Pennsylvania, has been mentioned in comparison to the "Battle of Pine Swamp." However, the Christiana event was very different because lives were lost on both sides. As a result, some resisters were tried and convicted of murder and other charges. In the case of Pine Swamp, there is no record of legal action against the resisters. In addition, the local constable who was enlisted to assist the captors under the false pretense that the escapee had stolen chickens, "at once told them he would have nothing to do with making the arrest and started home on foot." He had a very long walk, but he considered it infinitely more pleasant than to remain and assist such a man as George Alberti in carrying off a Negro and his family." (New Jersey Mirror, December 13, 1860)

${ }^{90}$ Guy Weston, "Finding Free African Americans During the Antebellum Period," "National Genealogical Society," Vol. 41: No. 1, p. 51.
} 
no such records as enslaved people, and even after slavery, many Southern states where the majority of postbellum Black people lived were among the very last to adopt regulations requiring the reporting of vital events. ${ }^{91}$ Future research in this area will use vital records to support efforts to estimate population sizes in Timbuctoo over time. In addition, these records can be used in efforts to find present-day descendants of early Timbuctoo settlers.

\section{Preserving and Protecting Timbuctoo in the Twenty-First Century}

Over the last decade, data sources above have provided a wide-ranging overview of people, institutions, and events related to Timbuctoo that were known earlier to a very small handful of researchers, or in many cases, not known at all. This compelling aspect of local history was not even routinely taught in local schools prior to a specialized 2018 curriculum project discussed below, such that descendants of nineteenth-century residents had no sense of the importance of their heritage from studying local history at school.

That all changed in 2009, when Temple University archaeologists Christopher Barton, David Orr, and colleagues began conducting archaeological research in collaboration with Westampton Township, local historians, members of the descendant community, and other volunteers. Most notably, the collaborative archaeology framework utilized by Barton and Orr called for meaningful engagement of descendants and other community members. This collaboration was realized through an advisory committee called the Timbuctoo Discovery Project. This committee included representation of all of the categories identified above. The collaboration also included key informant interviews with elder descendants. This process facilitated the

\footnotetext{
${ }^{91}$ Family Search, "U.S. Vital Records Overview," https://www.familysearch.org/wiki/en/U.S._Vital_Records_Overview. Retrieved on August 1, 2021.
} 
understanding of Timbuctoo's historic past as well as facilitated the interpretation of research findings. From the descendant perspective, this "facilitation" ranged from knowing that "Dixie Peach" jars found in excavation had contained a hair pomade popular in African American communities, to more complex and provocative discussions of racism, and constructions of race, class, and power in the present. ${ }^{92}$ The archaeological research got substantial press attention locally and nationally, raising Timbuctoo's profile in the local area as well as promoting discourse among researchers and outreach events to educate the community.

In 2015, Westampton Mayor Carolyn Chang empaneled a new committee as an official advisory committee of the Township's governing body. In this new paradigm, the committee was authorized by an ordinance, appointing the membership, and defining the committees' roles and responsibilities. These included advising the governing body on historic preservation issues related to Timbuctoo and conducting outreach activities to raise awareness of Timbuctoo's historic significance. At this point, the key event was an annual outdoor Timbuctoo Day, celebrated in September to commemorate the 1826 land purchases, including history lessons, cultural entertainment, recognition of descendant families, and other activities.

This committee also obtained corporate funding to install a road sign to mark the entrance to Timbuctoo in 2017 through a collaboration with American Legion Post 509. In 2018, funding was obtained from the Burlington County History Partnership Program and Wesley AME Zion Church to install four interpretive signs in the Timbuctoo Cemetery.

\footnotetext{
${ }^{92}$ Christopher P. Barton and Patricia G. Markert, "Collaborative Archaeology, Oral History, and Social Memory at Timbuctoo," New Jersey Journal of African Diaspora Archaeology and Heritage, Vol. 1, No. 1, Spring 2012.
} 
Figure 6. Interpretive Signage in the Timbuctoo Cemetery

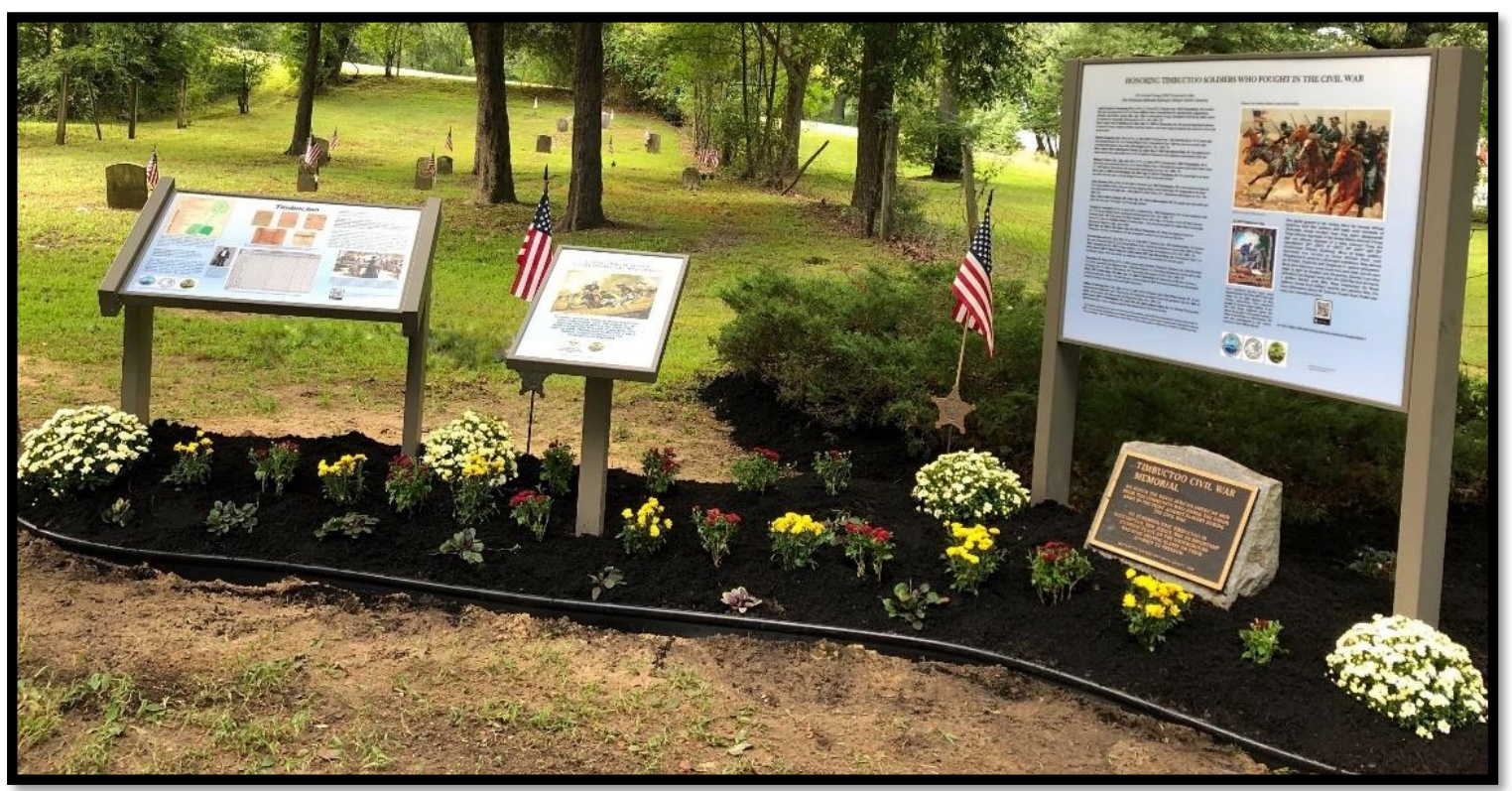

In 2019, county funding supported development of curricula and materials to include Timbuctoo in social studies lessons. In this case, local teachers were engaged to do the curriculum development and facilitate dissemination in the schools.

Also in 2019, the Timbuctoo Historical Society was founded to provide an independent mechanism to continue and expand historic preservation work. This was an important milestone, since the Timbuctoo Advisory Committee, as a municipal entity, cannot apply for foundation or corporate grants or do individual fundraising. This advisory committee also cannot own property. This became a critical limitation for preservation work in the 1854 Timbuctoo Cemetery, which had some title problems. In July of 2021, the Timbuctoo Historical Society obtained the title to the cemetery. This action will facilitate fundraising and dealing with the bureaucracy of obtaining permits required to do some preservation work. Other 2021 projects include filming a documentary with county funding and completing the application package to have Timbuctoo listed on the New 
Jersey and National Registers of Historic Places. Timbuctoo received a certification of eligibility for listing in 2011.

The mission of the Timbuctoo Historical Society is "to seek, document, preserve, interpret and perpetuate the history and heritage of Timbuctoo, an unincorporated community in Westampton Township, Burlington County, New Jersey, settled beginning in 1826 by formerly enslaved and free Black people.“

Celebrating Juneteenth in the context of Timbuctoo and New Jersey means conducting research to learn everything we possibly can about this First Emancipation as it relates to our heritage, finding creative ways to share research findings, create public awareness, promote engaging dialogue, and, occasionally, correct misinformation.

The dominant narrative of slavery in Southern states ending in the era of the Civil War cannot be ignored. That said, it is critical that the narrative of African American history also encompasses and celebrates our persistence, achievements, resistance, and resolve. Timbuctoo, and its captivating aspects such as the Battle of Pine Swamp, represent accomplishment and a sense of pride that we will continue to research and disseminate to offer a more complete picture of African American history during the antebellum period.

Research for this article supported in part by the Burlington County History Partnership Program with funding from the New Jersey Historical Commission.

Guy Weston has been engaged in genealogy research for over 25 years, with substantial focus on his maternal ancestors in Timbuctoo, New Jersey, where his fourth great-grandfather bought his family's plot in 1829 for $\$ 30$. His introduction to genealogy came when he had to do research to quiet the title on his family's parcel. More recently, he has been engaged in various research and public history initiatives to raise the profile of antebellum free African Americans in 
New Jersey history. These have included interpretive signage in Timbuctoo, coordination of a curriculum development project in collaboration with local teachers, and preservation efforts for the Timbuctoo cemetery, where the oldest gravestone is dated 1847.

Guy currently serves as managing director of the Timbuctoo Historical Society and is a visiting scholar at Rutgers University (New Brunswick) in the history department. In addition, he is active in the Association for the Study of African American Life and History (ASALH), and the Afro-American Historical and Genealogical Society (AAHGS). He also serves on the editorial board of AAHGS journal. He maintains a website, which can be found at timbuctoonj.com. He has a master's degree in bilingual-bicultural studies from LaSalle University. 